\title{
BaCk NuMBers
}

of the

\section{AMERICAN JOURNAL OF INTERNATIONAL LAW}

\section{and \\ PROCEEDINGS OF THE AMERICAN SOCIETY OF INTERNATIONAL LAW}

Tr

HE Society has in stock a limited supply of back numbers of the Journal in the original paper bindings for sale at $\$ 9.00$ an issue, as follows:

Complete volumes of the Journal are available for the years 1964, 1966, 1968, 1969, 1972, 1975, and 1976. Numbers available for other years are: 1919: January, April, July; 1931, 1967, 1970: January, April, October; 1927, 1930, 1951, 1963, 1965, 1971, 1973, 1974: April, July, October; 1925, 1943: April, July; 1921, 1928, 1936, 1938, 1949, 1959, 1960, 1961; July, October; 1922, 1953: January; 1926, 1952, 1957: July; 1918, 1929, 1937, 1947, 1955, 1962: October.

Supplement, 1935, Part I: Harvard Research Draft Convention and Comment on Extradition. 1928.

Special Supplements (paper or cloth): 1917, 1926,

Single issues of the current volume (1976) may be obtained at $\$ 9.00$ a còpy.

Proceedings are available for the years 1956-1958, $1961-1963,1965-1973$ at $\$ 9.00$ a volume.

Analytical Index to the Journal and Supplements, Vols. 35-54 (1941-1960) and Proceedings of the Society, 1941-1960. Cloth, $\$ 20.00$.

Orders should be sent to the American Journal of International Law 2223 Massachusetts Avenue, N.W., Washington, D. C. 20008 


\section{BACK VOLUMES \\ American Journal of International Law}

We are pleased to announce the reprinting of all out-of-print volumes by arrangement with the American Society of International Law. We invite your orders and inquiries:

Volumes 1-69 (1907-1975)

Including Supplements, Special Supplements and Analytical Indexes for Volumes 1-64

the set, bound $\$ 3620.00$

Main volumes

Supplement v. 1-25, 27, 28, 30-32, 34-49

Supplement v. $26,29,33$

Special Supplement v. 9-11, 20, 22, 23

Analytical Index v. 1-64 (4 vols.)

per vol. bound $\$ 39.50$

per vol. bound 17.50

per vol. bound 39.50

per vol. bound 22.50

4 vols. bound 85.00

\section{FRED B. ROTHMAN \& CO. South Hackensack, N.J. 07606}

\section{IJnternational Ilaw Aerspectibe}

To the acclaim of international lawyers and scholars worldwide, International Law Perspective is a timesaving and highly informative monthly report available to all those who are interested and concerned with current developments in international law within the United States. Each issue selects, summarizes, and highlights the important and interesting occurrences in the Congress, the courts, the legal periodicals, and other notable sources. All monthly issues are sent by first-class mail.

Subscription for 12 issues : U.S. \& Canada, $\$ 36.00$; Foreign, $\$ 40.00$

Make check payable to: International Law Perspective

927 15th Street, N.W.

Washington, D.C. 20005 


\section{The American Society of International Law}

The American Society of International Law was organized in 1906 "to foster the study of international law and to promote the establishment and maintenance of international relations on the basis of law and justice."

The Society serves as a meeting place and forum for scholars, teachers, officials, lawyers, and others, from some one hundred countries. In April, it holds a three-day Annual Meeting at which current problems of international law are discussed. The Society also sponsors regional meetings outside of Washington in cooperation with other institutions. Salient questions of international law and relations are considered in depth by panels and study groups organized by the Society's Board of Review and Development. Works of scholarship are often published under the Society's auspices in connection with studies sponsored by the Board, many in the Society's series of Studies in Transnational Legal Policy.

The Society periodically issues four publications:

The American Journal of International Law, the leading journal in the field of international law, has been published since 1907. The Proceedings of the American Society of International Law carries the papers and discussion of the annual meeting of the Society. Both are distributed to all members of the Society without additional charge, and are available to nonmembers at a subscription rate of $\$ 36$ a year.

International Legal Materials, a bimonthly, is a unique international collection of texts of current official documents, including legislation, treaties, court decisions, and reports. Subscription rates are $\$ 20$ a year for members of the Society, $\$ 55$ for others.

The quarterly Newsletter provides members with news of the Society and other organizations in the field.

Society membership is open to all persons of whatever nationality and profession who are interested in its objectives. Dues are: regular, $\$ 30$ for residents of the United States, $\$ 22$ for non-residents; professional, $\$ 40$; intermediate, $\$ 15$; student, $\$ 10$. ( $\$ 15$ of membership fee is allotted to AJIL subscription.) Membership application form is printed at the back of each issue of AJIL.

OFFICERS OF THE SOCIETY, 1977-1978

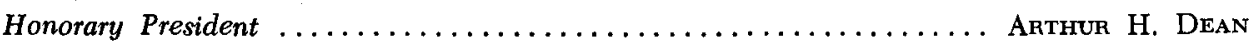

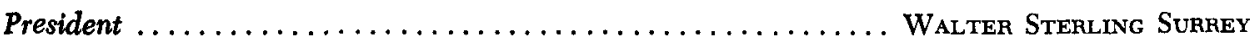

Vice Presidents ........... Alona E. Evans, C. Clyde Ferguson, Leonard C. Meeker

Executive Vice President and Executive Director ............... SEymour J. Rubin

Honorary Vice Presidents: Richafd R. Baxter, William W. Bishop, Jr., Herbert W. Briggs, Hardy C. Dillard, Leo Gross, John N. Hazard, James N. Hyde, Philip C. Jessup, Harold D. Lasswell, Monroe Leigh, Brunson MacChesney, Myres S. McDougal, Franz M. Oppenheimer, William D. Rogers, Dean Rusk, Oscar Schachter, John R. Stevenson, Marjorie M. Whiteman.

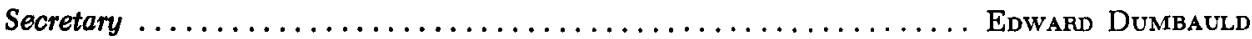

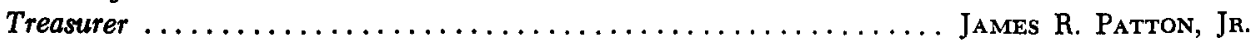

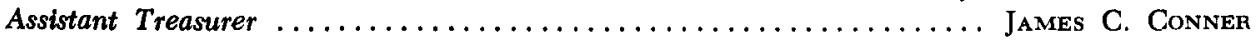




\section{International}
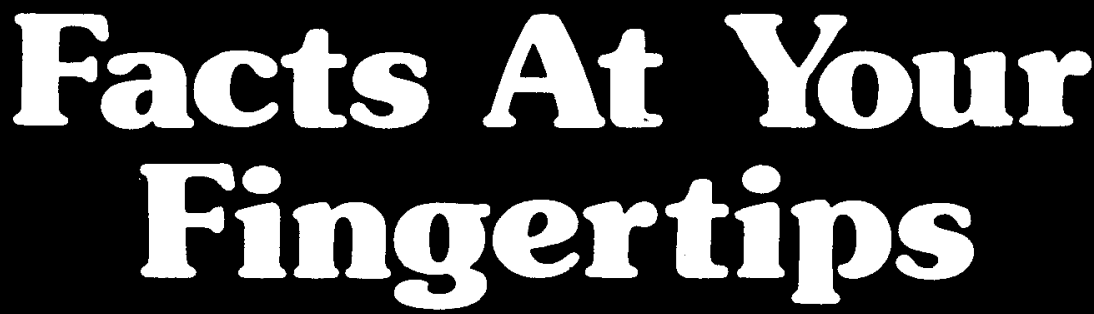

1

What has the Law of the Sea Conference accomplished?

9 What is the International Chamber of Commerce doing about a code of conduct for multinational corporations?

2. Can U.S. Court deci2 sions be enforced in the United Kingdom?

4 What is the United States doing about foreign boycotts?

5 What's being done to protect the Rhine against pollution?

(5) How have uranium the market price?
7 When can foreign diplomats claim immunity to suit in U.S. Courts?

What is OPEC doing to - help developing countries? Is Andean integration
working?

10

What progress has been made on an international agreement to end corrupt business practices?

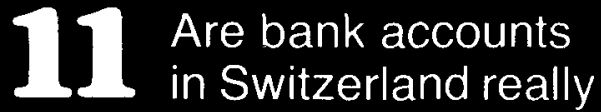
anonymous?

12 Do foreign fishermen need permits to fish in U.S. waters?

International Legal Materials has the Answers to all these Questions and More. Have the facts before the secondary sources provide the analysis. Reach an objective understanding of current issues by examining the official texts of treaties, legislation, Court decisions, declarations, draft proposals, and memoranda that affect international relations and global interdependence.

Order from ILM, the American Society of International Law, 2223 Mass. Ave., N.W., Washington, D.C. 20008. \$20 for ASIL members; $\$ 55$ for non-members.

Name

Address

City State Zip 


\section{Join-}

\section{THE AMERICAN SOCIETY OF INTERNATIONAL LAW}

As a member of the Soclety, you will receive

- four issues each year of the most distinguished journal in the field, THE AMERICAN JOURNAL OF INTERNATIONAL LAW.

- the PROCEEDINGS of the Society's Annual Meeting.

- the opportunity to buy other Society publications at reduced prices, such as the valuable bimonthly documentary, INTERNATIONAL LEGAL MATERIALS, and books published under Society auspices such as THE VIETNAM WAR AND INTERNATIONAL LAW.

- the Society's NEWSLETTER, which keeps you abreast of developments in the field.

- the opportunity to participate in significant, Society-sponsored meetings (the Annual Meeting, regional meetings, study panels).

- occasion to join with others in contributing to the development of international law through the Society's wide-ranging studies and publications.

If you wish to join the Society, please clip out this page, fill out the application on the reverse side, and mail it, together with your check, to the Membership Secretary, American Society of International Law, 2223 Massachusetts Avenue, N.W., Washington, D. C. 20008. You will receive the Journal and Newsletter for the current year.

Members of whatever profession and nationality are welcome.

If you or your institution prefers to subscribe to the Journal, without joining the Society, please so indicate on the reverse side. 
Membership Secretary

American Society of International Law

2023 Massachusetts Avenue, N.W.

Washington, D.C. 20008

Please enroll me as a member of the American Society of International Law. My check, money order, UNESCO coupon, or payment in a convertible currency, is enclosed. I have checked the category of membership for which I am eligible:

[ ] PROFESSIONAL MEMBERS (U.S. residents practicing law other than in government who have been members of the bar for more than 10 years ) $\ldots \ldots \ldots \ldots \ldots \ldots \ldots \ldots \ldots \$ 40$

[ ] RESIDENT REGULAR MEMBERS-residing in the United

States

[ ] NON-RESIDENT MEMBERS-not residing in the United States

( ] INTERMEDIATE MEMBERS (first 5 years of membership for those under 30 years of age at time of application) . . \$ 15

l ] STUDENT MEMBERS $\ldots \ldots \ldots \ldots \ldots \ldots \ldots \ldots \ldots \ldots \ldots \$ 10$

l ] CONTRIBUTING MEMBERS $\ldots \ldots \ldots \ldots \ldots \ldots \ldots \ldots \$ \$ 50$

[ ] SUPPORTING MEMBERS $\ldots \ldots \ldots \ldots \ldots \ldots \ldots \ldots \ldots \$ 100$

\ ] ANNUAL PATRON $\ldots \ldots \ldots \ldots \ldots \ldots \ldots \ldots \ldots \ldots$

[ ] LIFE $\ldots \ldots \ldots \ldots \ldots \ldots \ldots \ldots \ldots \ldots \ldots \ldots \ldots \ldots \ldots \ldots \ldots$

( $\$ 15$ of membership fee is allotted to AJIL subscription)

(Please Print)

Name

Mailing Address

Zip

Professional Affiliation:

Nationality

Particular professional interests:

Signature

PLEASE MAKE CHECKS PAYABLE TO The American Society of International Law. Contributions above obligatory dues, and all dues if membership is related to your work or profession, are tax deductible in the United States.

Please enter my subscription for the Journal at $\$ 36$ a year 